\title{
Microsatellite based DNA fingerprinting of 28 local rice (Oryza sativa L.) varieties of Bangladesh
}

\author{
M. S. Rahman, M. K. H. Sohag and L. Rahman \\ Genetic Fingerprinting Laboratory, Department of Genetics and Plant Breeding, Bangladesh Agricultural University, \\ Mymensingh-2202, Bangladesh
}

\begin{abstract}
A total of 28 local rice (Oryza sativa L.) varieties of Bangladesh were selected for DNA fingerprinting with seven microsatellite DNA markers. Upon PCR amplification the alleles were separated on Agarose gel using a sequencing gel electrophoresis system. The loci were polymorphic $\left(\mathrm{P}_{95}\right)$ in all of the varieties. Variation was found in number of alleles, allele frequency, observed and expected heterozygosity. The primer, RM335 having motif (CTT) 20 also yielded highest number of alleles (15) and highest PIC value (0.909). Genetic differentiation $\left(F_{\text {st }}\right)$ values were found in the ranges 0.84 to 1.00 with an average of 0.92 and gene flow $\left(\mathrm{N}_{\mathrm{m}}\right)$ values ranged from 0.047 to 0.00 with an average of 0.02 . High level genetic differentiation and low level gene flow values in 28 rice (Oryza sativa L.) varieties which were indicated of diversity among the varieties as most of these varieties were of landraces. Over all Nei's genetic distance value (D) ranged from nil to 2.56 among 378 varietals pairs resulting as a means of permutation combination of 28 rice varieties. The UPGMA dendrograme based on Nei's genetic distance placed the varieties into different clusters. All of the varieties were identified with at least one and/or combination of 7 primers.
\end{abstract}

Keywords: Microsatellites, DNA fingerprinting, Oryza sativa, Bangladesh

\section{Introduction}

Rice, Oryza sativa $(2 n=24)$ belongs to the family Gramineae and subfamily Oryzoidae. Rice is the most important food crop, providing the staple food for nearly half of the global population especially in Asia, Africa, and Latin America (FAO, 2004). Rice is central to Bangladesh's economy and agriculture, providing about $75 \%$ of the calorie and $55 \%$ of the protein in the average daily diet of the people (Anonymous, 2002). Asian farmers have selected and maintained a vast variety of rice strains over thousands of years. Up till now, about 7,500 varieties have been collected and preserved in the gene bank from indigenous and exotic sources by BRRI. Out of these, nearly 5,000 varieties have been registered in the gene bank. A duplicate set of BRRI germplasm is maintained at the Genetic Resources Centre (GRC) at IRRI, for safe keeping and long-term storage as the base collection (http://banglapedia.search.com.bd/HT/G_0072.htm). Large variations of rice in respect of morphological, biochemical and DNA traits exist in Asia, as its center of origin with sub-centers of diversity more particularly in China and Indian subcontinent (Baki et al., 2000; Noldin, 2000; Chen et al., 2001). According to Zhimin (1999), there has been a theory that rice originated in Assam of India and Yunan of China is mostly agriculturally biased. Assam a Northeast state of India resembling Yunan province of China is on the Himalayan sub-tropic plateau. The Assam center is the closest area of Bangladesh, which is also a part of the center of origin of Javanica rice types with abundance of $O$. rufipogon $\mathrm{L}$. and $O$. nivara L., the two possible immediate ancestors of the O. sativa L. (Chang, 1984).

In rice, microsatellites are abundant and well distributed throughout the genome (Akagi et al., 1996; McCouch et al., 1997). They are valuable as genetic markers because they are codominant, detect high levels of allelic diversity, and are assayed efficiency by the Polymerase Chain Reaction (McCouch et al., 1997). Microsatellites are PCR-based markers that are both technically efficient and cost-effective to use and are available for rice (Chen et al., 1997; Temnykh et al., 2000). Previous studies in rice have contributed to the development of several hundred microsatellite markers and a genetic map consisting of 320 SSRs (Akagi et al., 1996; Panaud et al., 1996; Chen et al., 1997; Temnykh et al., 2000. 2001). For characterization and documentation, this technique has been recently used in crop species including rice, wheat, maize, barley, rapeseed, soybean, potato and other crops by Rahman et al., (2006, 2007). In Bangladesh, 9 soybean cultivars were identified by microsatellite markers, which have provided identity and might work as protection (Islam et al., 2007). Thirteen maize cultivars were also characterized using microsatellite fingerprinting in combination with DUS test (Molla et al., 2007). Cai and Morishima (2000) assayed sixty eight Bangladesh landraces together with 22 Asian check varieties, 8 isozyme loci by PAGE and revealed results similar to that of Glaszmann (1987). 


\section{Materials and Methods}

Seeds of the local rice varieties were collected from Genetic Resource and Seed Division (GRSD) of Bangladesh Rice Research Institute (BRRI). The varieties were grown and molecular characterizations were done in the Genetic Fingerprinting Laboratory of the Department of Genetics and Plant Breeding during the period of August/2008- January/2009.

\section{Raising of Seedlings and isolation of genomic DNA}

10-12 seeds of each variety were selected randomly and dried in oven at $54^{\circ} \mathrm{C}$ for $48 \mathrm{hrs}$ for better germination. After germination in the wet blotting paper in petridishes, the seedlings were grown in small plastic pots. Bulked DNA was isolated from 2-5 juvenile culms of 15-day-old seedlings of each of 28 rice varieties/cultivars following the protocol described by Aljanabi and Martinez (1997) and also used by Rahman et al., (2007) with some modifications. Excluding usage of CTAB, the modified protocol included digestion with homogenization buffer (Solution: Tris-50 mM, EDTA-25 mM, NaCl-300 mM, 1\% SDS and deionized water) at $65^{\circ} \mathrm{C}$ for 30 min, extraction with phenol: chloroform: isoamyl alcohol (25:24:1), precipitation with ice-cold and extra pure isopropyl alcohol and purification with absolute ethanol (Plus sodium acetate, $3 \mathrm{M}$ ) and $70 \%$ ethanol chronologically. Finally, DNA sample of each rice variety dissolving in 30-40 $\mu \mathrm{l}$ of TE buffer within $1.5 \mathrm{ml}$ eppendorf tube was preserved separately at $-20^{\circ} \mathrm{C}$. Presence of genomic DNA was confirmed on $1 \%$ agarose gel qualitatively.

\section{Quantification and optimization of DNA concentration}

The amount of genomic DNA was quantified at $260 \mathrm{~nm}$ spectrophotometrically (Spectronic ${ }^{\circledR}$ Genesis $^{\mathrm{TM}}{ }^{2}$ ). Using the absorbance reading obtained for DNA sample of each rice variety, the original DNA concentrations were determined and adjusted to $25 \mathrm{ng} / \mu \mathrm{l}$.

\section{Identification and selection of microsatellite/SSR primers}

A set of seventeen microsatellite primer pairs (RM5, RM55, RM105, RM151, RM153, RM170, RM206, RM264, RM266, RM278, RM287, RM307, RM333, RM334, RM335 RM475 and RM481) distributed in the rice genome were identified from the available data-based search (http://www.gramene.org/) for rice SSR markers as described by Akagi et al. (1996), Panaud et al. (1996), Temnykh et al. (2000, 2001) and McCouch et al. (2002). From those identified primers, at first 3 to 5 primers were tested against 5 randomly selected varieties with a recommended PCR thermal profile. Based on better responsiveness in amplifying the target genomic region of template DNA, the expected PCR product sizes in base pairs was then going to check. The selected Primers were then screened against 28 varieties at a time. In this way seven primer pairs viz. RM153, RM206, RM251, RM307, RM333, RM335 and RM475 representing chromosome numbers 5, 11, 3, 4,10, 4, and 2 of rice genome (Temnykh et al., 2001) with clear and expected amplified product sizes were selected and used for microsatellite analysis in the present study. One (RM153) and two (RM153 and RM335) of these primers were used in the study for molecular characterization of 34 rice varieties (Rahman, et al., 2006) and 94 rice varieties (Rahman, et al., 2007) respectively.

\section{Polymerase chain reaction (PCR)}

Polymerase chain reaction were done in a volume of $10 \mu$ l containing 10x PCR Buffer, $0.25 \mathrm{mM}$ each of the dNTPs. $1 \mu \mathrm{M}$ of each of primer, 1 unit ampli Taq DNA polymerase, $50 \mathrm{ng}$ template DNA and a suitable amount of sterile deionized water. Amplification was carried out in a oil free thermal cycler (Thermal cycler gradient, Eppendorf) with the following thermal profile: initial denaturation step at $94^{\circ} \mathrm{C}$ for $3 \mathrm{~min}$. followed by 35 cycles at $95^{\circ} \mathrm{C}$ for $30 \mathrm{sec}$. $55^{\circ} \mathrm{C}$ for $30 \mathrm{sec}$. and $72^{\circ} \mathrm{C}$ for $1 \mathrm{~min}$. and a final cycle at $72^{\circ} \mathrm{C}$ for $7 \mathrm{~min}$. PCR was confirmed by electrophoresis on $2 \%$ agarose gel.

\section{Electrophoretic separation and visualization of PCR products}

PCR was confirmed by electrophoresis on $2 \%$ agarose gel. Prior to electrophoresis each PCR-products was prepared with loading dye $(0.25 \%$ xylene cyanol, $0.25 \%$ bromophenol blue, $30 \%$ glycerol and $1 \mathrm{mM}$ EDTA). Loading dye was used for monitoring the loading and the progress of electrophoresis and to increase the weight of the sample so that it stayed in the well of the gel. A molecular weight marker DNA 
(100 bp) was loaded on either side of the gel. The gel was carefully placed in the electrophoresis gel chamber (Blue Marine Serva) keeping the gel horizontal and submerged in 1× TBE buffer (running buffer) and final level of buffer was $\sim 5 \mathrm{~mm}$ above the gel. Electrophoresis was performed at $100 \mathrm{~V}$ for 1 hour and 30 minutes using the power supply (EPS 301, Amersham, Pharmacia Biotech). The DNA migrate from negetive to positive electrode (black to red). The electrophoresis was stopped after the bromophenol blue dye had reached three-fourths of the gel length.PCR-products were electrophoresed on a $2 \%$ Agarose gel. Electrophoresis was done using the SequiGen GT Sequencing Gell (BIO-RAD Laboratories, Hercules, CA) electrophoresis system. Before running the gel, the power supply which connects with gel chamber was set for $2 \mathrm{hrs}$ and 40 minutes, $100 \mathrm{~V}$ and $50 \mathrm{~W}$. For documentation, the gel was taken out from the electrophoresis chamber and placed on the high performance ultraviolet transilluminator (UVP, BioDoc-It ${ }^{\mathrm{TM}}$ System) at the wave-length of $302 \mathrm{~nm}$ to observe the quality of the genomic DNA. Then the gel was examined and was photographed by using a Gel Cam Polaroid camera and finally saved in computer.

\section{Scoring and analysis of microsatellite data}

Microsatellite DNA profiles of all rice varieties against seven primers are shown in Fig. 1. Photograph from Gel Cam Polaroid camera was printed on $20 \mathrm{~cm}$ X $25 \mathrm{~cm}$ graph paper. The bands representing particular alleles at the microsatellite loci were scored manually and designated the bands as A, B, C, etc. from the top to the bottom of the gel by four experienced scientists individually. The genotypes of different individuals were hypothetically scored as $A A, B B, C C$, etc. for homozygous or as $A B, A C, B C$ etc. for heterozygous. A single genotypic data matrix was constructed for all loci. Polymorphism Information Content (PIC) was computed by deducting sum of square values for all the frequencies of different alleles produced by a single marker locus from one using the formula: $\mathrm{PIC}=1-\Sigma \mathrm{Xi}^{2}$, where, $\mathrm{Xi}$ is the frequency of the i-th allele of a particular locus. PIC provides an estimate of the discriminatory power of a marker by taking into account, not only the number of alleles that are expressed, but also the relative frequencies of those alleles. PIC values range from 0 (monomorphic) to 1 (very high discriminative, with many alleles in equal frequencies). The software DNA FRAG version 3.03 was used to estimate allelic length (Nash, 1991). Expected $(\mathrm{He})$ and observed heterozygosity (Ho) were also calculated as per Nei (1972) formula and with the help of POPGENE (version 1.31) (Yeh et al., 1999) computer package program. Estimation of Nei's genetic distance values (D) (Nei, 1972) and construction of UPGMA (Unweighted Pair Group Method of Arithmetic Means) dendrogram was constructed using the software POPGENE (Version 1.31) (Yeh et al., 1999).

\section{Results and Discussion}

Unlike morphological and biochemical markers, DNA markers are unlimited in numbers and are not affected by environmental factors and /or the developmental stages of the plant (Ovesna et al., 2002, Saker et al., 2005). The genetic markers arise from different classes of DNA mutations such as substitution mutation, rearrangements or errors in replication of tandemly repeated DNA.

The PIC values are dependent on the genetic diversity of the cultivars chosen and this investigation had a high proportion of traditional varieties which would have the effect of increasing the PIC values. It is important to indicate that the selection by breeders have increased the frequency of the alleles or allelic combination with favorable effects at the expense of the others, eventually eliminating many of them (Cao et al., 1998). The markers in the specific chromosome and the allele size along with their frequencies and PIC values have been shown in the Table 1.

Using 7 primers across 28 rice varieties, a total of 82 alleles were found in the present study of which RM333 and RM335 showed highest number of observed number of alleles (15) followed by RM307 (14), RM251 (12), RM206 (11), RM475 (9) and RM153 (6) in descending order (Table 1). RM333 and RM335 showed highest number of alleles but effective number of allele was only highest (11.042) for RM335 (Table 2). Rahman et al. (2006, 2008) reported 18 and 78 alleles respectively while analyzing with 3 primers (RM11; RM151 and RM153) \& 5 primers (RM1; RM151; RM153; RM334 and RM335) in which PIC values were $0.670 ; 0.707 ; 0.698 \& 0.862 ; 0.923 ; 0.831 ; 0.865$ and 0.910 respectively. Yang et al., (1994) found up to 25 alleles for 10 microsatellite markers among 238 accessions of Indica and Japonica cultivars and landraces. 
Table 1. Size and frequency of alleles and diversity index at 7 SSR loci across 28 rice (Oryza sativa L.) varieties

\begin{tabular}{|c|c|c|c|c|c|c|c|c|}
\hline Allele & $\begin{array}{c}\text { RM-153 } \\
\text { (Chromosome 5) }\end{array}$ & $\begin{array}{c}\text { RM-206 } \\
\text { (Chromosome 11) }\end{array}$ & $\begin{array}{c}\text { RM-251 } \\
\text { (Chromosome 3) }\end{array}$ & $\begin{array}{c}\text { RM-307 } \\
\text { (Chromosome 4) }\end{array}$ & $\begin{array}{c}\text { M-333 } \\
\text { (Chromosome 10) }\end{array}$ & $\begin{array}{c}\text { RM-335 } \\
\text { (Chromosome 4) }\end{array}$ & $\begin{array}{c}\text { RM-475 } \\
\text { (Chromosome } \\
2 \text { ) } \\
\end{array}$ & Average \\
\hline Allele A & 0.0357 & 0.0714 & 0.0357 & 0.0357 & 0.0714 & 0.0179 & 0.1071 & \\
\hline Allele B & 0.0357 & 0.0179 & 0.0536 & 0.0179 & 0.0357 & 0.0179 & 0.0179 & \\
\hline Allele C & 0.2857 & 0.0893 & 0.0179 & 0.0179 & 0.0357 & 0.0357 & 0.0714 & \\
\hline Allele D & 0.3214 & 0.0714 & 0.0893 & 0.0714 & 0.0357 & 0.0714 & 0.1429 & \\
\hline Allele $\mathrm{E}$ & 0.2143 & 0.1071 & 0.0536 & 0.0893 & 0.0357 & 0.0536 & 0.2500 & \\
\hline Allele $\mathrm{F}$ & 0.1071 & 0.0357 & 0.2143 & 0.1250 & 0.0714 & 0.0357 & 0.1964 & \\
\hline Allele G & & 0.0714 & 0.1429 & 0.0357 & 0.0714 & 0.0893 & 0.1250 & \\
\hline Allele $\mathrm{H}$ & & 0.1786 & 0.1071 & 0.0357 & 0.0357 & 0.0536 & 0.0357 & \\
\hline Allele I & & 0.2321 & 0.0357 & 0.1250 & 0.2321 & 0.0536 & 0.0536 & \\
\hline Allele J & & 0.0714 & 0.1250 & 0.0714 & 0.0714 & 0.0714 & & \\
\hline Allele K & & 0.0536 & 0.1071 & 0.0357 & 0.1071 & 0.1429 & & \\
\hline Allele $\mathrm{L}$ & & & 0.0179 & 0.1607 & 0.0714 & 0.1607 & & \\
\hline Allele M & & & & 0.1429 & 0.0357 & 0.0893 & & \\
\hline Allele $\mathrm{N}$ & & & & 0.0357 & 0.0536 & 0.0714 & & \\
\hline Allele $\mathrm{O}$ & & & & & 0.0357 & 0.0357 & & \\
\hline Diversity Index $\left(\mathrm{PIC}=1-\sum X \mathrm{X}^{2}\right)$ & 0.755 & 0.869 & 0.878 & 0.897 & 0.897 & 0.909 & 0.841 & 0.864 \\
\hline Observed number of alleles & 6 & 11 & 12 & 14 & 15 & 15 & 9 & 11.71 \\
\hline $\begin{array}{l}\text { Effective number of alleles } \\
\text { [Kimura and Crow (1964)] }\end{array}$ & 4.0833 & 7.6863 & 8.2094 & 9.7391 & 9.7391 & 11.0423 & 6.3226 & 8.117 \\
\hline$\%$ Of Effectiveness & 68.05 & 69.88 & 68.41 & 69.57 & 64.93 & 73.61 & 70.25 & 69.243 \\
\hline \multirow[t]{2}{*}{ Sequence of primers $\left(5^{\prime}-3^{\prime}\right)$} & F: gcctcgagcatcatcatcag & F: cccatgcgtttaactattct & F: gaatggcaatggcgctag & $\begin{array}{c}\mathrm{F}: \\
\text { gtactaccgacctaccgttcac }\end{array}$ & $\begin{array}{c}\mathrm{F}: \\
\text { gtacgactacgagtgtcaccaa }\end{array}$ & $\begin{array}{l}\text { F: gtt cag tgt tca gtg } \\
\text { cca cc }\end{array}$ & \begin{tabular}{|c|}
$\mathrm{F}:$ \\
cctcacgatttcctc \\
caac \\
\end{tabular} & \\
\hline & R: atcaacctgcacttgcctgg & R: cgttccatcgatccgtatgg & R: atgcggttcaagattcgatc & R: ctgctatgcatgaactgctc & R: gtcttcgcgatcactcgc & $\begin{array}{l}\text { R: gaa cag aga aca } \\
\text { gag cca cc }\end{array}$ & \begin{tabular}{|c|}
$\mathrm{R}:$ \\
$\begin{array}{c}\text { acggtgggattaga } \\
\text { ctgtgc }\end{array}$ \\
\end{tabular} & \\
\hline Motif & $(\text { gaa })_{9}$ & $(\mathrm{ct})_{21}$ & $(\mathrm{ct})_{29}$ & $(\mathrm{at})_{14}(\mathrm{gt})_{21}$ & $(\mathrm{tat})_{19}(\mathrm{ctt})_{19}$ & $(\mathrm{CTT})_{20}$ & $($ tatc) 8 & \\
\hline
\end{tabular}

\section{Table 2. Summary of genetic variation and heterozygosity statistics for all loci}

\begin{tabular}{|c|c|c|c|c|c|c|c|c|c|c|c|}
\hline Locus & $\mathrm{na}^{*}$ & $n e^{*}$ & $I^{*}$ & Fst & $\mathrm{Nm}^{*}$ & Obs_Hom & Obs_Het & Exp_Hom* & Exp_Het ${ }^{*}$ & $\mathrm{Nei}^{* *}$ & Ave_Het \\
\hline RM153 & 6.0000 & 4.0833 & 1.5302 & 1.0000 & 0.0000 & 1.0000 & 0.0000 & 0.2312 & 0.7688 & 0.7551 & 0.0000 \\
\hline RM206 & 11.0000 & 7.6863 & 2.2034 & 0.9179 & 0.0224 & 0.8571 & 0.1429 & 0.1143 & 0.8857 & 0.8699 & 0.0714 \\
\hline RM251 & 12.0000 & 8.2094 & 2.2577 & 0.8983 & 0.0283 & 0.8214 & 0.1786 & 0.1058 & 0.8942 & 0.8782 & 0.0893 \\
\hline RM307 & 14.0000 & 9.7391 & 2.4232 & 0.9204 & 0.0216 & 0.8571 & 0.1429 & 0.0864 & 0.9136 & 0.8973 & 0.0714 \\
\hline M333 & 15.0000 & 9.7391 & 2.5107 & 0.9801 & 0.0051 & 0.9643 & 0.0357 & 0.0864 & 0.9136 & 0.8973 & 0.0179 \\
\hline RM335 & 15.0000 & 11.0423 & 2.5399 & 0.8429 & 0.0466 & 0.7143 & 0.2857 & 0.0740 & 0.9260 & 0.9094 & 0.1429 \\
\hline RM475 & 9.0000 & 6.3226 & 1.9797 & 0.9152 & 0.0232 & 0.8571 & 0.1429 & 0.1429 & 0.8571 & 0.8418 & 0.0714 \\
\hline Mean & 11.7143 & 8.1174 & 2.2064 & 0.9232 & 0.0208 & 0.8673 & 0.1327 & 0.1201 & 0.8799 & 0.8642 & 0.0663 \\
\hline St. Dev & 3.3523 & 2.3631 & 0.3564 & 0.0482 & 0.0141 & 0.0938 & 0.0938 & 0.0540 & 0.0540 & 0.0530 & 0.0469 \\
\hline
\end{tabular}

*na $=$ Observed number of alleles, ne = Effective number of alleles, I = Shannon's Information Index and Nm = Gene flow estimated from Fst $=0.25(1-$ Fst $) / F s t$.

* Expected homozygosity and heterozygosity were computed using Levene (1949)

** Nei's (1973) expected heterozygosity 


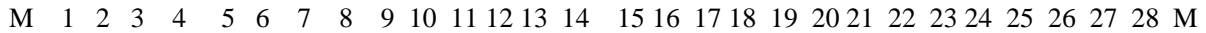

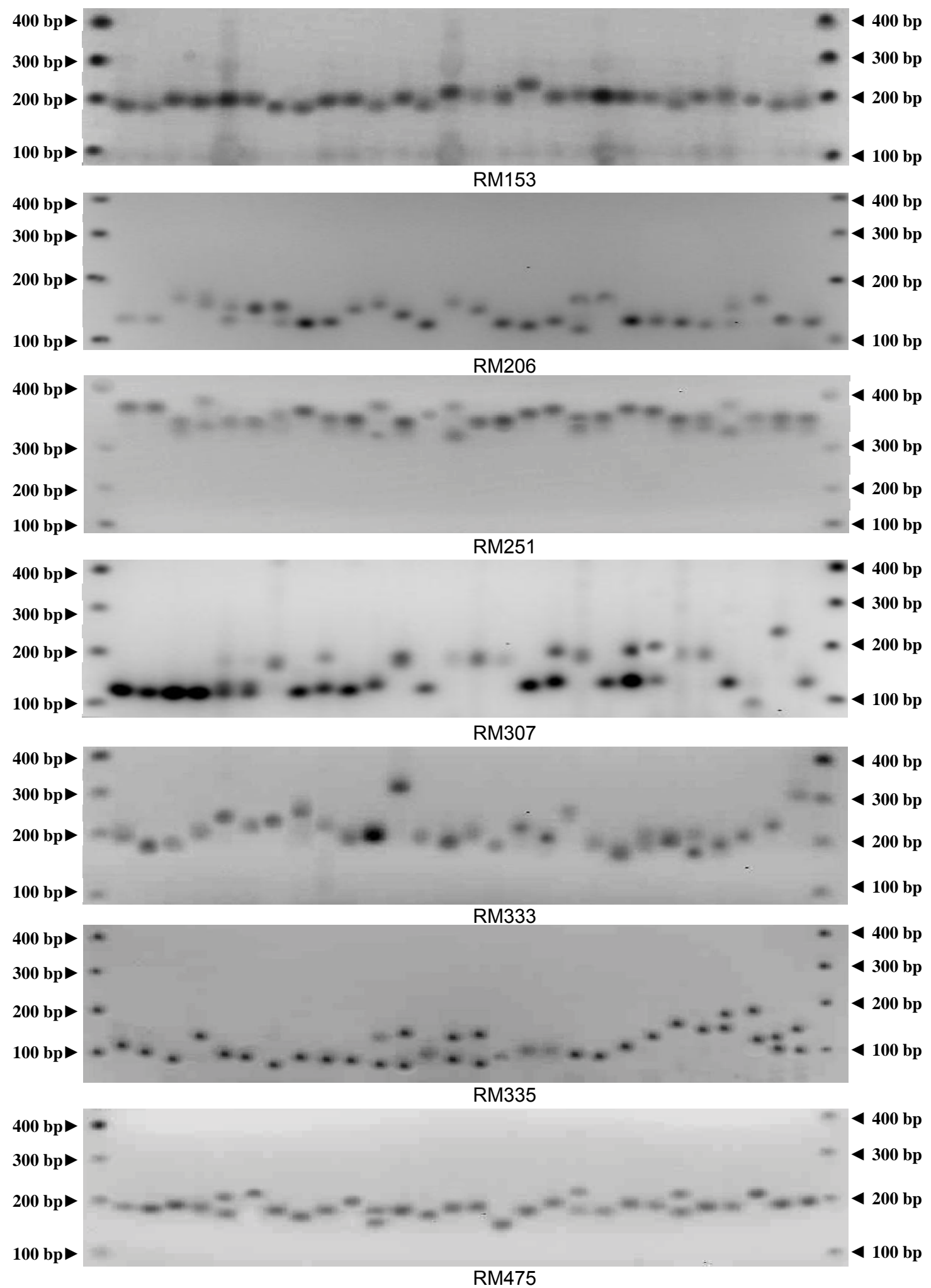

Fig. 1. A microsatellite profiles of 28 rice varieties of Bangladesh at loci, RM153, RM251, RM333, RM335 and RM475, where each consecutive lane represents a single variety. Lane, 1=Lal Amon, 2=Lau Jan, 3=Nara Aswina, 4=Buna Dhan, 5=Begun Bechi, 6=Bhasha Manik, 7=Kochu Dhola, 8=Sunga Wala, 9=Konek Chul, 10=Horinkhur Panati, 11=Ganjia, 12=Dudhsar, 13=Mathia, 14=Khirma Pat, 15=Mukut Sail, 16=Ban Kolom, 17=Safa Har (3), 18=Kal Nania, 19=Shil Pan, 20=Jabar Sail, 21=Moisha Mida, 22=Paglakushyari, 23=Pan Kaich, 24=Lal Patjat, 25=Chandda Gotok, 26=Moisha Mira, 27=Choia Mora, 28=Modhu Maloti 
The PIC values for 7 primers obtained in the present study varied from 0.755 for RM153 to 0.909 for RM335, with an average PIC value of 0.864 (Table 1). Among the markers used in this study RM335 showed higher PIC values than the others. Lower PIC value may be the result of closely related genotypes and higher PIC values might be the result of diverse genotypes. The number of alleles amplified by a primer and its PIC values also depends upon the repeat number and the repeat sequence of the microsatellite sequences (Temnykh, et al., 2000, 2001; Yu et al., 2003; Ni et al., 2002). Ni et al., (2002) showed that larger repeats and GA- repeats yield higher number of alleles and higher PIC values. Contrary to this, Temnykh et al., (2000) showed that (CTT), and AT-rich trinucleotide repeats amplified with higher efficiency and revealed greater polymorphism overall. RM334 and RM333 having (CTT) repeat were two most informative microsatellite markers for this set of germplasm, as they yielded 6-7 alleles and had PIC value 0.8 (Temnykh et al., 2001). For RM333 [(CTT)19] and RM335[(CTT)20], we observed 15 alleles and PIC value of 0.897 and 0.909 , respectively which were not unusual based on repeat number and the repeat motif to that of reported by Temnykh et al., (2001).

Crossing over and mutation are likely to be occurred more frequently at the distant locations from the centromere position of a chromosome and therefore, enhance the possibility of forming more alleles and heterozygosity of a particular locus (Rahman et al., 2008). Temnykh et al. (2001) reported that the loci, RM153; RM206; RM251; RM307; RM333; RM335 and RM475 are located at $0.00 \mathrm{cM} ; 102.9 \mathrm{cM} ; 79.1$ $\mathrm{cM} ; 0.00 \mathrm{cM} ; 110.4 \mathrm{cM} ; 21.5 \mathrm{cM}$ and $92.5 \mathrm{cM}$ position, respectively on chromosome $5 ; 11 ; 3 ; 4 ; 10 ; 4$ and 2 of rice (Oryza sativa L.). These have been used in the present study of 28 conventional rice varieties.

Genetic differentiation (Fst) values were found in the ranges of 0.84 to 1.00 with an average of 0.923 and gene flow $(\mathrm{Nm})$ values ranged from 0.000 to 0.047 with an average of 0.021 (Table 2). Gao (2005) reported overall genetic differentiation and gene flow values of 0.442 and 0.316 , respectively, while examined with 14 microsatellite loci in different populations of Oryza officinalis Wall. ex Watt. We observed comparatively high level of genetic differentiation and low level of gene flow values in 28 rice $(0$. sativa L.) varieties which are indicative of diversity among the varieties as most of the studied varieties were of land races and HYVs. In the present study, variation was found in number of alleles, allele frequency, observed and expected heterozygosity. Across 28 rice varieties, RM335 yielded highest average heterozygosity (0.142) followed by RM251 (0.089), RM206, RM307, and RM475 (0.0714) and RM153 (0.000) in descending order (Table 2). Highest heterozygosity could be explained by length, distance of RM335 on genetic map relative to centromere. The primers have been found to identify different numbers of alleles having a range between 6 in case of RM153 and 15 in case of RM335 and RM333 respectively.

Over all Nei's genetic distance value (D) ranged from nil to 2.56 among 378 varietal pairs resulting as a means of permutation combination of 28 rice varieties (Table 3). Out of 378 varietals pairs $38.89 \%$ pairs showed no genetic distance. Among the varietal pairs, $1.85 \%$ pairs were found to show highest (2.56) distance. UPGMA (The Unweighted Pair-Group Method with Arithmetic Mean) dendrogram based on Nei's (1972) genetic distance (Table 3) indicated segregation of 28 genotypes of rice into two main clusters: In cluster 1 Lal Amon, Nara Aswina, Safa Har (3), Khirma Pat, Shil Pan, Madhu Maloti, Sunga Wala, Horinkhur Panati, Mathia, Chandda Gotok, Moisha Mira, Dudshar, Ban Kolom, Jabar Sail, Pan KaichICGV, formed sub-cluster II. Subcluster I and Subcluster II again clustering according to their genetic distance. Lau Jan, Bhasha Manik, Mukut Sail, Choia Mora, Kochu Dhola, Konen Chul, Lal Patjat, Buna Dhan, Begun bechi, Moisha Mida, Ganjia, Kal Nania and Paglakushyari grouped in cluster 2. The highest genetic distance can be explained by the fact that in one side the varieties were from the land races and on the other side the HYVs have been involved. The distance has been generated during the process of the development of HYVs. The generated distance can further be used for inclusion of gene source from the traditional varieties to more HYVs, which indicates the impact of the genetic fingerprinting and correlating the values with that of the morpho-physiological traits to find out the best performing varieties through appropriate breeding programmes. 
Table 3. Summary of Nei's (1972) genetic distance values between 28 Local Rice (Arachis hypogaea L.) varieties for all loci

\begin{tabular}{|c|c|c|c|c|c|c|c|c|c|c|c|c|c|c|c|c|c|c|c|c|c|c|c|c|c|c|c|c|}
\hline${ }^{*}$ Pop ID & 1 & 2 & 3 & 4 & 5 & 6 & 7 & 8 & 9 & 10 & 11 & 12 & 13 & 14 & 15 & 16 & 17 & 18 & 19 & 20 & 21 & 22 & 23 & 24 & 25 & 26 & 27 & 28 \\
\hline 1 & ** & & & & & & & & & & & & & & & & & & & & & & & & & & & \\
\hline 2 & 1.25 & ** & & & & & & & & & & & & & & & & & & & & & & & & & & \\
\hline 3 & 0.00 & 1.95 & $* *$ & & & & & & & & & & & & & & & & & & & & & & & & & \\
\hline 4 & 1.22 & 1.91 & 1.50 & ** & & & & & & & & & & & & & & & & & & & & & & & & \\
\hline 5 & 1.46 & 1.46 & 1.87 & 0.00 & ** & & & & & & & & & & & & & & & & & & & & & & & \\
\hline 6 & 1.95 & 0.00 & 1.25 & 0.00 & 1.18 & ** & & & & & & & & & & & & & & & & & & & & & & \\
\hline 7 & 2.60 & 0.99 & 0.00 & 0.00 & 2.53 & 0.00 & ** & & & & & & & & & & & & & & & & & & & & & \\
\hline 8 & 1.95 & 0.85 & 1.95 & \begin{tabular}{|l|}
1.91 \\
\end{tabular} & 2.56 & 0.00 & 1.50 & ** & & & & & & & & & & & & & & & & & & & & \\
\hline 9 & 2.60 & 0.00 & 1.91 & 0.00 & 1.14 & 1.50 & 0.00 & 1.91 & ** & & & & & & & & & & & & & & & & & & & \\
\hline 10 & 1.95 & 0.00 & 1.95 & 1.91 & 0.95 & 1.25 & 2.60 & 0.00 & 0.99 & ** & & & & & & & & & & & & & & & & & & \\
\hline 11 & 1.42 & 1.83 & 0.00 & 0.54 & 0.00 & 0.00 & 2.48 & 0.00 & 0.00 & 1.42 & ** & & & & & & & & & & & & & & & & & \\
\hline 12 & 0.00 & 1.91 & 1.91 & 0.00 & 1.14 & 1.91 & 1.87 & 0.00 & 1.47 & 1.50 & 2.08 & ** & & & & & & & & & & & & & & & & \\
\hline 13 & 1.95 & 1.95 & 0.00 & \begin{tabular}{|l|}
1.91 \\
\end{tabular} & 1.46 & 0.00 & 1.91 & 0.00 & 1.91 & 0.00 & 1.83 & 0.00 & ** & & & & & & & & & & & & & & & \\
\hline 14 & 1.18 & 0.00 & 1.46 & 1.83 & 0.00 & 2.56 & 0.00 & 2.56 & 2.53 & 0.00 & 3.14 & 1.61 & 0.00 & ** & & & & & & & & & & & & & & \\
\hline 15 & 1.91 & 0.00 & 1.91 & 0.96 & 2.53 & 0.00 & 2.55 & 2.60 & 1.87 & 1.22 & 1.79 & 1.87 & 0.00 & 1.14 & ** & & & & & & & & & & & & & \\
\hline 16 & 1.95 & 1.95 & 1.95 & 0.00 & 2.56 & 1.95 & 2.60 & 1.95 & 0.00 & 0.00 & 2.52 & 0.00 & 0.00 & 2.56 & 1.91 & ** & & & & & & & & & & & & \\
\hline 17 & 0.00 & 1.95 & 0.00 & 0.00 & 0.00 & 0.00 & 1.22 & 0.00 & 1.91 & 0.00 & 1.42 & 1.91 & 1.25 & 0.00 & 0.00 & 0.00 & ** & & & & & & & & & & & \\
\hline 18 & 1.22 & 1.91 & 1.22 & 0.00 & 1.43 & 1.91 & 2.55 & 1.22 & 1.87 & 1.91 & 0.00 & 1.87 & 0.00 & 1.43 & 0.00 & 1.91 & 1.91 & ${ }^{* *}$ & & & & & & & & & & \\
\hline 19 & 0.00 & 1.42 & 0.00 & 0.00 & 1.75 & 1.83 & 2.48 & 0.00 & 0.00 & 0.00 & 3.09 & 2.48 & 1.83 & 0.00 & 1.79 & 1.13 & 2.52 & 0.00 & ${ }^{* *}$ & & & & & & & & & \\
\hline 20 & 0.00 & 0.00 & 1.95 & 0.00 & 2.56 & 1.95 & 0.00 & 0.00 & 1.22 & 1.95 & 0.00 & 0.00 & 1.95 & 2.56 & 1.91 & 1.25 & 0.00 & 2.60 & 1.83 & $* *$ & & & & & & & & \\
\hline 21 & 0.00 & 0.00 & 1.91 & 0.00 & 0.00 & 0.00 & 0.00 & 1.91 & 1.87 & 0.00 & 0.00 & 0.00 & 0.00 & 2.53 & 1.87 & 1.50 & 0.00 & 1.18 & 1.38 & 1.91 & ${ }^{* *}$ & & & & & & & \\
\hline 22 & 1.91 & 0.00 & 0.00 & 1.87 & 0.00 & 0.00 & 0.00 & 0.00 & 1.87 & 0.00 & 0.00 & 0.00 & 1.91 & 1.83 & 0.96 & 1.91 & 0.00 & 0.00 & 1.79 & 1.91 & 1.06 & ${ }^{* *}$ & & & & & & \\
\hline 23 & 0.00 & 2.60 & 1.91 & 1.87 & 1.14 & 1.50 & 2.55 & 0.00 & 1.18 & 1.22 & 1.57 & 0.96 & 0.00 & 0.00 & 1.87 & 0.00 & 2.60 & 1.87 & 2.48 & 0.00 & 1.87 & 1.87 & ${ }^{* *}$ & & & & & \\
\hline 24 & 1.91 & 0.00 & 2.60 & 1.47 & 1.83 & 0.00 & 0.00 & 0.00 & 0.00 & 2.60 & 2.48 & 1.87 & 0.00 & 1.83 & 0.96 & 1.91 & 0.00 & 0.00 & 1.38 & 1.91 & 1.87 & 1.18 & 0.96 & ${ }^{* *}$ & & & & \\
\hline 25 & 1.13 & 1.83 & 2.52 & 1.79 & 3.14 & 0.00 & 3.17 & 2.52 & 0.00 & 0.00 & 3.09 & 0.00 & 0.00 & 1.34 & 1.10 & \begin{tabular}{|l|}
1.13 \\
\end{tabular} & \begin{tabular}{|l|}
0.00 \\
\end{tabular} & 1.79 & 1.70 & 0.73 & 1.79 & 1.10 & 0.00 & 0.87 & ${ }^{* *}$ & & & \\
\hline 26 & 0.00 & 0.00 & 1.91 & 1.47 & 1.83 & 1.22 & 0.00 & 0.00 & 1.18 & 0.81 & 1.57 & 1.87 & 0.00 & 0.00 & 1.87 & 0.00 & 0.00 & 1.87 & 2.48 & 1.22 & 0.00 & 0.00 & 0.96 & 2.55 & 0.00 & $* *$ & & \\
\hline 27 & 1.91 & 0.00 & 1.91 & 1.47 & 1.83 & 0.00 & 1.87 & 0.00 & 0.00 & 0.00 & 1.57 & 1.18 & 1.91 & 0.00 & 0.00 & 0.00 & 0.00 & 1.87 & 0.00 & 0.00 & 1.47 & 0.00 & 1.87 & 1.87 & 0.00 & 3.26 & ** & \\
\hline 28 & 1.50 & 0.00 & 0.00 & 1.87 & 1.83 & 0.00 & 0.00 & 0.00 & 1.87 & 1.91 & 1.79 & 1.18 & 1.91 & 0.00 & 0.00 & 0.00 & 0.00 & 2.55 & 0.00 & 1.91 & 1.87 & 1.87 & 1.18 & 1.47 & 1.57 & 0.00 & 1.18 & ** \\
\hline
\end{tabular}

*Pop ID Variety

1 Lal Amon

2 Lau Jan

3 Nara Aswina

4 Buna Dhan

5 Begun Bechi

6 Bhasha Manik

7 Kochu Dhola
Pop ID Variety

8 Sunga wala

9 Konek Chul

10 Horinkhur Panati

11 Ganjia

12 Dudssar

13 Mathia

14 Khirma Pat

Pop$$
\text { Pop ID Variety }
$$

15 Mukut Sail

16 Bankolom

Safa Har (3)

Kal Nania

Shul Pan

Jabar Sail

Moisha Mida
Pop ID Variety

22 Paglakushyari

23 Pan Kaich

24 Lal Patjat

25 Chandda Gotok

26 Moisha Mira

28 Modhu Maloti 
Attempt was made to distinguish and identify all the varieties from one another with at least one and/or combination of 7 primers. Comparative microsatellite profiles and DNA band positions against 7 SSR primers (Table 4). Rahman et al. (2006 and 2008 ) identified 29 varieties during characterization of 34 rice varieties with 3 microsatellite markers and 93 varieties during characterization of 94 rice varieties with 5 microsatellite markers.

Table 4. Comparisons between SSR band position and selected Breeder's traits of distinctness of the rice varieties

\begin{tabular}{|c|c|c|c|c|c|c|c|c|c|}
\hline \multirow{2}{*}{ SI. No } & \multirow{2}{*}{ Variety Name } & \multirow{2}{*}{ Distinguishing primer(s) } & \multicolumn{7}{|c|}{ Band positions due to primers (bp) } \\
\hline & & & RM153 & RM206 & RM251 & $\mathrm{RM} 307$ & RM 333 & RM335 & RM475 \\
\hline 1 & Lal Amon & RM333 & 191 & 119 & 108 & 108 & 194 & 106 & 178 \\
\hline 2 & Lau Jan & RM333 & 184 & 119 & 108 & 104 & 171 & 88 & 173 \\
\hline 3 & Nara Aswina & RM333 & 195 & 150 & 149 & 104 & 182 & 84 & 185 \\
\hline 4 & Buna Dhan & RM251 & 191 & 145 & 149,104 & 104 & 207 & 120 & 178 \\
\hline 5 & Begun Bechi & RM333/RM475 & 195 & 139,119 & 140 & 108 & 242 & 88 & 200,167 \\
\hline 6 & Bhasha Manik & RM206/RM251/RM333 & 195 & 134 & 145 & 108 & 212 & 84 & 205 \\
\hline 7 & Kochu Dhola & RM307/RM335 & 184 & 139,119 & 126 & 152 & 228 & 69 & 173 \\
\hline 8 & Sunga Wala & RM333/RM475 & 184 & 119 & 113 & 104 & 296 & 79 & 161 \\
\hline 9 & Konek Chul & RM307 & 195 & 124 & 133 & 164,108 & 220 & 79 & 173 \\
\hline 10 & Horinkhur Panati & RM335 & 195 & 139 & 133 & 108 & 207 & 74 & 190 \\
\hline 11 & Ganjia & RM251/RM335/RM475 & 191 & 145 & 176,108 & 119 & 207 & 120,74 & 173,151 \\
\hline 12 & Dudhsar & RM206/RM333/RM335 & 195 & 129 & 140 & 164 & 319 & 125,74 & 173 \\
\hline 13 & Mathia & RM307 & 191 & 114 & 126 & 113 & 207 & 88 & 167 \\
\hline 14 & Khirma Pat & RM153/RM251/RM335 & 206 & 150 & 176,113 & 164 & 200 & 125,84 & 178 \\
\hline 15 & Mukut Sail & RM335 & 200 & 139 & 149 & 164 & 207 & 130,79 & 178 \\
\hline 16 & Ban Kolom & RM333/RM475 & 200 & 119 & 149 & 170 & 235 & 84 & 151 \\
\hline 17 & Safa Har (3) & RM153 & 222 & 114 & 126 & 119 & 220 & 95 & 173 \\
\hline 18 & Kal Nania & RM307 & 200 & 119 & 113 & 182,124 & 207 & 95 & 185 \\
\hline 19 & Shil Pan & RM206/RM251/RM333/RM475 & 200 & 156,110 & 154,145 & 170 & 256 & 88 & 210,173 \\
\hline 20 & Jabar Sail & RM153 + RM251 & 200 & 161 & 133 & 124 & 188 & 84 & 167 \\
\hline 21 & Moisha Mida & RM307/RM333/RM335 & 200 & 124 & 113 & 170,129 & 169 & 100 & 185 \\
\hline 22 & Paglakushyari & RM251/RM307/RM335 & 200 & 124 & 120 & 195,129 & 200 & 130 & 178 \\
\hline 23 & Pan Kaich & RM335/RM475 & 195 & 124 & 140 & 176 & 200 & 154 & 205,173 \\
\hline 24 & Lal Patjat & RM206/RM333/RM335 & 200 & 110 & 140 & 176 & 207,176 & 142 & 178 \\
\hline 25 & Chandda Gotok & RM206/RM251/RM335 & 200 & 150,119 & 162,108 & 124 & 188 & 175,142 & 178 \\
\hline 26 & Moisha Mira & RM206/RM307/RM335 & 195 & 161 & 133 & 95 & 207 & 180,120 & 205 \\
\hline 27 & Choia Mora & RM307/RM335 & 191 & 129 & 140 & 229 & 228 & 120,100 & 185 \\
\hline 28 & Modhu Maloti & RM335 & 191 & 124 & 140 & 124 & 319 & 142,106 & 190 \\
\hline
\end{tabular}




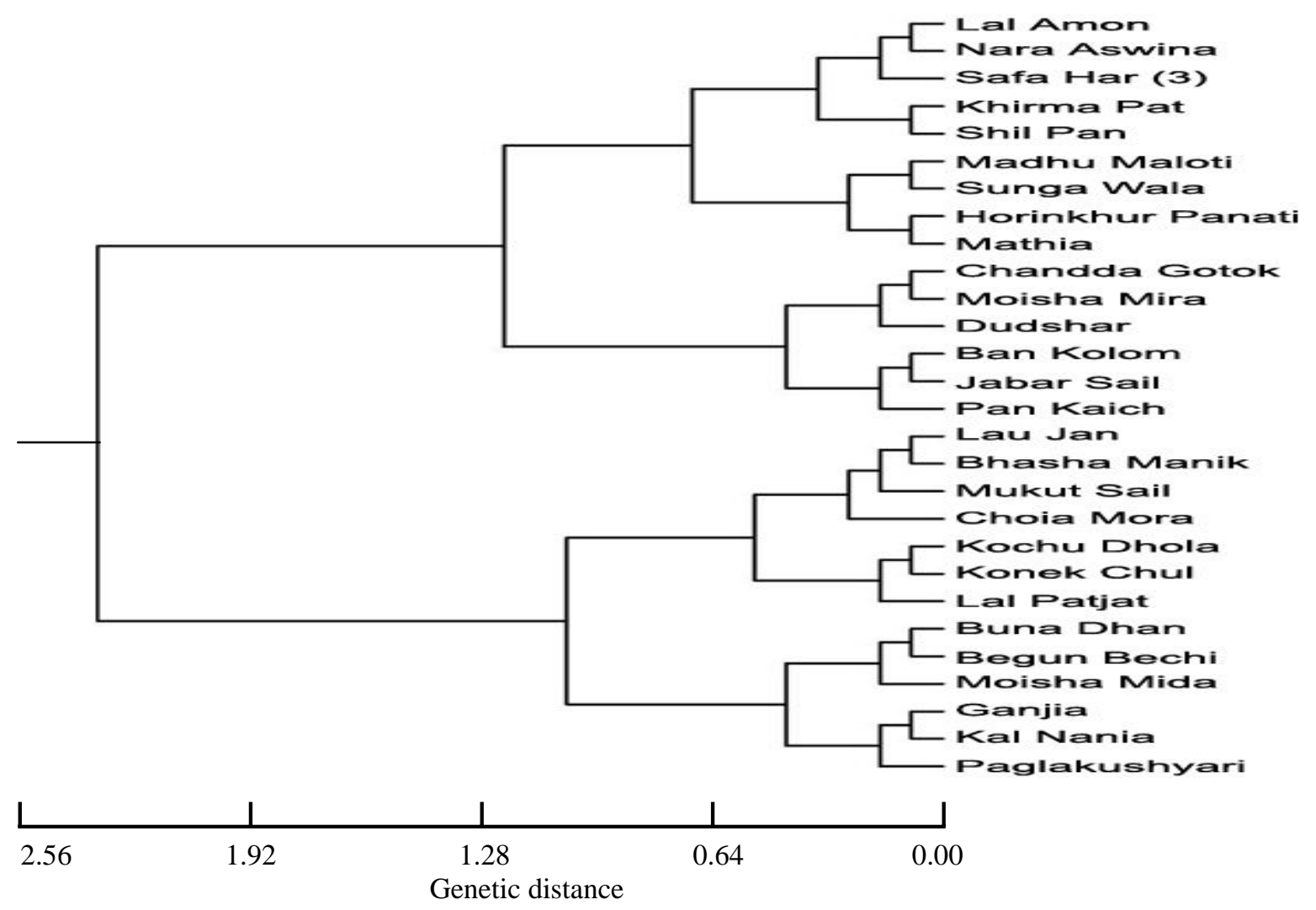

Fig. 2. UPGMA dendrogram based on Nei's (1972) genetic distance, summarizing the data on differentiation between 28 local rice varieties according to microsatellite

\section{Conclusion}

The present study showed average number of alleles of all the rice genotypes were 11.71 over the seven microsatellite loci. The coefficient of population differentiation $\left(F_{s t}\right)$ and gene flow $\left(N_{m}\right)$ values across all the loci were 0.92 and 0.02 respectively. The Unweighted Pair Group Method of Arithmetic Mean (UPGMA) dendrogram based on Nei's (1972) genetic distance, resulted in two major clusters with several sub cluster. Through the present study, a total of 28 variety's specific alleles were identified with specific SSR primer. The result of the present study would be useful to know genetic variation, population structure, parentage assessment, genome mapping, Marker Assisted Selection (MAS), forensics, stock purity, etc. of different populations of the studied species before undertaking any breeding any breeding program, and also will be used as baseline information for further study. However, more extensive molecular data is needed in order to draw and conclusive remarks about the relationship between rice cultivars. Large number of samples would be necessary to determine if there are inherent differences in genetic distance between the rice cultivars. Moreover, using higher number of markers would give a clear idea about the genetic variation and genetic diversity which might be of greater interest for the plant breeders for the development of rice varieties.

\section{Acknowledgement}

Authors express thanks to the DANIDA for supporting this research work through the Agriculture Extension Component/Seed Wing of the Ministry of Agriculture, Government of the People's Republic of Bangladesh. In the same line, they extend their thanks to Mr. Anwar Faruqe, Joint Secretary MoA and Director General of the Seed Wing, for his support to and keen interest in the project activities. 


\section{References}

Akagi, H., Yokozeki, Y., Inagaki, A. and Fujimura, T. 1996. Microsatellite DNA markers for rice chromosomes. Theor. Appl. Genet. 93: 1071-1077.

Aljanabi S.M. and Martinez, I. 1997. Universal and rapid salt-extraction of high quality genomic DNA for PCR-based techniques. Nucleic Acids Res. 25: 4692-4693.

Anonymous, 2002. National Workshop on Rice Research and Extension-2002. Feeding the extra millions by 2025. Bangladesh Rice Research Inst. Gazipur, p: 1.

Baki, B.B., Chin, D.V. and Mortimer, M. (eds). 2000. Wild and weedy rice in rice ecosystems in Asia - a review. Los Baños, Philippines: International Rice Research Institute, 118.

Bligh, H.F.J., Blackhall, N.W., Edwards, K.J. and McClung, A.M. 1999. Using amplified fragment length polymorphisms and simple sequence length polymorphisms to identify cultivars of brown and white milled rice. Crop Sci. 39: 1715-1721.

Cai, H.W. and Morishima, H. 2000a. Diversity of rice varieties and cropping system in Bangladesh deepwater areas. JARQ. http://ss.jircas.affrc.go.jp/kankoubutsu/jarq/34-4/cai/cai.html.

Cao, T, Duprez, E., Borden, K.L.B., Freemont, P.S. and Etkin, L.D. 1998. Ret finger protein is a normal component of PML nuclear bodies and interacts directly with PML. J. Cell Sci. 111: 1319-1329.

Chang, T.T. 1984. Rice: Oryza sativa and Oryza Glaberrima. In: Crop plants evolution Edited by NW Simmonds. Longman, England and New York. pp. 98-104.

Chen, L.J., Suh, H.S. and Lee, D.S. 2001. Evolutionary significance of Chinese weedy rice 'Lu-tao'. SABRAO Journal of Breeding and Genetics. 33(2): 99-109.

Chen, X., Temnykh, S., Xu, Y., Cho, Y.G. and McCouch, S.R. 1997. Development of a microsatellite framework map providing genome-wide coverage in rice (Oryza sativa L.). Theor. Appl. Genet. 95: 553-567.

FAO (Food and Agriculture Organization of the United Nations). 2004. The State of Food and Agriculture 2003-2004.Agricultural Biotechnology: Meeting the Needs of the Poor? (1 June 2005; www.fao.org/docrep/)

Gao, L.Z. 2005. Microsatellite variation within and among populations of Oryza officinalis (Poaceae), an endangered wild rice from China. Mol. Ecol. 14: 4287-4297.

Garland, S.H., Lewin, L., Abedinia, M., Henry, R. and Blakeney, A. 1999. The use of microsatellite polymorphisms for the identification of Australian breeding lines of rice (Oryza sativa L.). Euphytica. 108: 53-63.

Glaszmann, J.C. 1987. Isozymes and classification of Asian rice varieties. Theor. Appl. Genet. 74: 21-30.

Islam, M.N., Molla, M.R. and Rahman, L. 2007. Microsatellite allele size profiling to identify and distinguish soybean cultivars in Bangladesh. Progress. Agric. 18 (1): 9-17.

Levene, H. 1949. On a matching problem arising in genetics. Ann. Math. Stat. 20: 91-94.

Mailer, R.J., Scarth, R. and Fristensky, B. 1994. Discrimination among cultivars of rapeseed (Brassica napus L.) using DNA polymorphism amplified from arbitrary primers. Theor. Appl. Genet. 87: 697-704.

Marshall, P., Marchand, M.C., Lisieczko, Z. and Landry, B.S. 1994. A simple method to estimate the percentage of hybridity in canola (Brassica napus) F1 hybrids. Theor. Appl. Genet. 89: 853-858.

McCouch, S.R., Teytelman, L., Xu, Y., Lobos, K.B., Clare, K., Walton, M., Fu, B., Maghirang, R., Li, Z., Xing, Y., Zhang, Q., Kono, I., Yano, M., Fjellstrom, R., DeClerck, G., Schneider, D., Cartinhour, S., Ware, D. and Stein, L. 2002. Development and Mapping of 2240 New SSR Markers for Rice (Oryza sativa L.). DNA Res. 9:199 - 207.

McCouch, S.R., X. Chen, O. Panaud, S. Temnykh, Y. Xu, Y.G. Cho, N. Huang, T. Ishii and M. Blair. 1997. Microsatellite marker development, mapping and applications in rice genetics and breeding. Plant Mol. Biol. 35(1/2): 89-99.

Molla, M.R., Islam, M.N. and Rahman, L. 2007. DNA fingerprinting of maize (Zea mays linn.) cultivars of Bangladesh using SSR markers. Bangladesh J. Crop Sci. 18 (1): 63-72.

Nash, J.H.E. 1991. DNAfrag, Version 3.03. Institute for biological sciences, National Research Council of Canada, Ottawa, Ontario, Canada.

Nei, M. 1972. Genetic distance between populations. Am. Natur. 106: 283-292.

Nei, M. 1973. Analysis of gene diversity in subdivided populations. Proc. Natl. Acad. Sci. USA, 70: 3321-3323.

Ni, J., Colowit, P.M. and Mackill, D.J. 2002. Evaluation of genetic diversity in rice subspecies using microsatellite markers. Crop Sci. 42: $601-607$.

Noldin, J.A. 2000. Red rice status and management in Americas. In: Baki BB, Chin DV, Mortimer M., eds. Wild and weedy rice in rice ecosystems in Asia - a review. Los Baños, Philippines: International Rice Research Institute, 21-24.

Ovesna, J., Polakova, K. and Lisova, L. 2002. DNA analyses and their applications in plant breeding. Czech. J. Genet. Plant Breed. 38: $29-40$. 
Panaud, O., Chen, X. and McCouch, S.R. 1996. Development of microsatellite markers and characterization of simple sequence length polymorphism (SSLP) in rice (Oryza sativa L.). Mol. Gen. Genet. 252: 597-607.

Rahman, L., Islam, M.N., Rahmam, M.S. and Islam, M.S. 2008. PLANT VARIETIES OF BANGLADESH: Morphological and Molecular Characterization. Published by Seed Wing, Ministry of Agriculture, Government of the Peoples' Republic of Bangladesh, Vol. 2, 300 p. [In press]

Rahman, L., Molla, M.R., Sultana, S., Islam, M.N., Ahmed, N.U., Rahman, M.S. and Nazim-ud-Dowla, M. 2007. PLANT VARIETIES OF BANGLADESH: Morphological and Molecular Characterization. Published by Seed Wing, Ministry of Agriculture, Government of the Peoples' Republic of Bangladesh, Vol. 1, 486 p.

Rahman, L., Molla, M.R., Sultana, S., Islam, M.N., Ahmed, N.U., Rahman, M.S., Nazim-ud-Dowla, M., Shah-E-Alam, M. and Alam, M.S. 2006 Plant Varieties of Bangladesh-Morphological and Molecular characterization for plant variety protection. Bangladesh J. Agricult,Sci. 33 (2): 215-225.

Saker, M.M., Youssef, S.S., Abdallah, N.A., Bashandy, H.S. and El Sharkawy, A.M. 2005. Genetic analysis of some Egyptian rice genotypes using RAPD, SSR and AFLP. African J. Biotechnol. 4 (9): 882-890.

Temnykh, S., DeClerck, G. Lukashova, A. Lipovich, L., Cartinhour, S. and McCouch, S.R. 2001. Computational and experimental analysis of microsatellites in rice (Oryza sativa L.), frequency, length variation, transposon associations and genetic marker potential. Genome Res. 11: 1441-1452.

Temnykh, S., Park, W.D., Ayres, N., Cartinhour, S., Hauck, N., Lipovich, L., Cho, Y.G., Ishii, T. and McCouch, S.R. 2000. Mapping and genome organization of microsatellite sequences in rice (Oryza sativa L.). Theor. Appl. Genet. 100: 697-712.

Yang, G.P., Maroof, M., Xu, C., Zhang, Q. and Biyashev, R. 1994. Comparative analysis of microsatellite DNA polymorphism inland races and cultivars of rice. Mol. Gen. Genet. 245: 187-194.

Yeh, F.C., Yang, R.C. and Boyle, T. 1999. POPGENE VERSION 1.31: Microsoft Window-based free Software for Population Genetic Analysis, 1999, ftp://ftp.microsoft.com/Softlib/HPGL.EXE.

Yu, S.B., Xu, W.J., Vijayakumar, C.H.M., Ali, J., Fu, B.Y., Xu, J.L., Jiang, Y.Z., Marghirang, R., Domingo, J., Aquino, C., Virmani, S.S. and Li, Z.K. 2003. Molecular diversity and multilocus organization of the parental lines used in the International Rice Molecular Breeding Program. Theor Appl Genet. 108:131-140.

Zhimin A. 1999. Origin of chinese rice cultivation and its spread east. http://http-server.carleton. ca/ bgordon/Rice/ papers/zhimin99.htm. 